\title{
CUSTOMER PERCEPTIONS OF HOSPITALITY SERVICES AT SOME HERITAGE SITES IN EGYPT
}

\author{
Fatma Mohammed Abdel-aal
}

\section{Faculty of Tourism and Hotel Management}

\author{
Helwan University
}

\begin{abstract}
This research investigates customer perceptions of hospitality services at three main Egyptian heritage sites Cairo, Luxor and Minia. The research evaluates service quality of hospitality services from the customer perspective in order to develop quality services that meet customer expectations and achieve customer satisfaction. A questionnaire, developed using SERVQUAL instrument, was distributed to customers in hotels around the three heritage sites. The findings showed a gap between customer expectations and perceptions of hospitality services, reflecting poor quality services and dissatisfaction with these services. The factors of quality hospitality service at these three Egyptian sites were identified to help hospitality managers and decision makers to provide their customers with appropriate service quality that meets international standards and also meet customer expectations.
\end{abstract}

Key Words: Heritage sites, hospitality services, customer expectations, customer perceptions, customer satisfaction, service quality, SERVQUAL, Egypt

\section{Introduction}

Egypt has been recognized worldwide as a distinguished tourism destination and a unique world-class heritage site. Therefore, hospitality organisations at the Egyptian heritage sites should provide services that meet needs, requirements and expectations of both national and international visitors/customers. Customers play a key role in business survival and success as they have the potential to create, sustain or destroy reputations through comments to other potential customers or through the media (Douglas and Connor, 2003). Therefore, customer satisfaction and loyalty, secured through high service quality, are essential for the destination competitiveness and long-term survival (Clark and Wood, 1998; Roblendo, 2001). Customer satisfaction is important because it leads to positive behaviour intentions, such as repurchase or return patronage (Venetis and Ghauri, 2004). Customer satisfaction also increases profitability, market share, and return on investment (Hacle and Westlund, 2000). However, studies on customer satisfaction and service quality in the hospitality context in developing countries, i.g. Egypt, have remained limited. The present study aims to evaluate service quality of hospitality services in and around three Egyptian heritages sites, using SERVQUAL model, by comparing visitor or customer expectations with their actual perceptions of hospitality services.

Parasuraman et al. (1985) measured quality in service organisations by separately scoring customer expectations and perceptions. Parasuraman et al. (1985) have developed and refined a questionnaire instrument called SERVQUAL. This was designed to elicit customer expectations and actual perceptions of quality attributes. The SERVQUAL has been classed instrument into five major dimensions (see Table 1).

The purpose of the SERVQUAL models is to provide the appropriate level of service quality based on the proposed dimensions and to identify where gaps in service exist and to what extent. This theory has been developed into a gap model (see the figure). The gap model helps analyse possible sources of quality problems through identification of five gaps or discrepancies.

The current study focuses on gap no 5 which reflects that perceived service falls short of the expectations of customers. This gap have called "service quality" gap of "customer satisfaction" gap. 
Table 1: The five SERVQUAL attributes

\begin{tabular}{|l|l|}
\hline Designation & \multicolumn{1}{|c|}{ Example } \\
\hline Tangibles & $\begin{array}{l}\text { the appearance of physical facilities, equipment, personnel and communications } \\
\text { materials }\end{array}$ \\
\hline Reliability & the ability to perform the promised service dependably and accurately \\
\hline Responsiveness & the willingness to help customers and provide prompt service \\
\hline Assurance & $\begin{array}{l}\text { the competence of the system and its credibility in providing a courteous and } \\
\text { secure service }\end{array}$ \\
\hline Empathy & the approachability, eases of access effort taken to understand customers' needs \\
\hline
\end{tabular}

Source: Zeithmal et al. (1990)

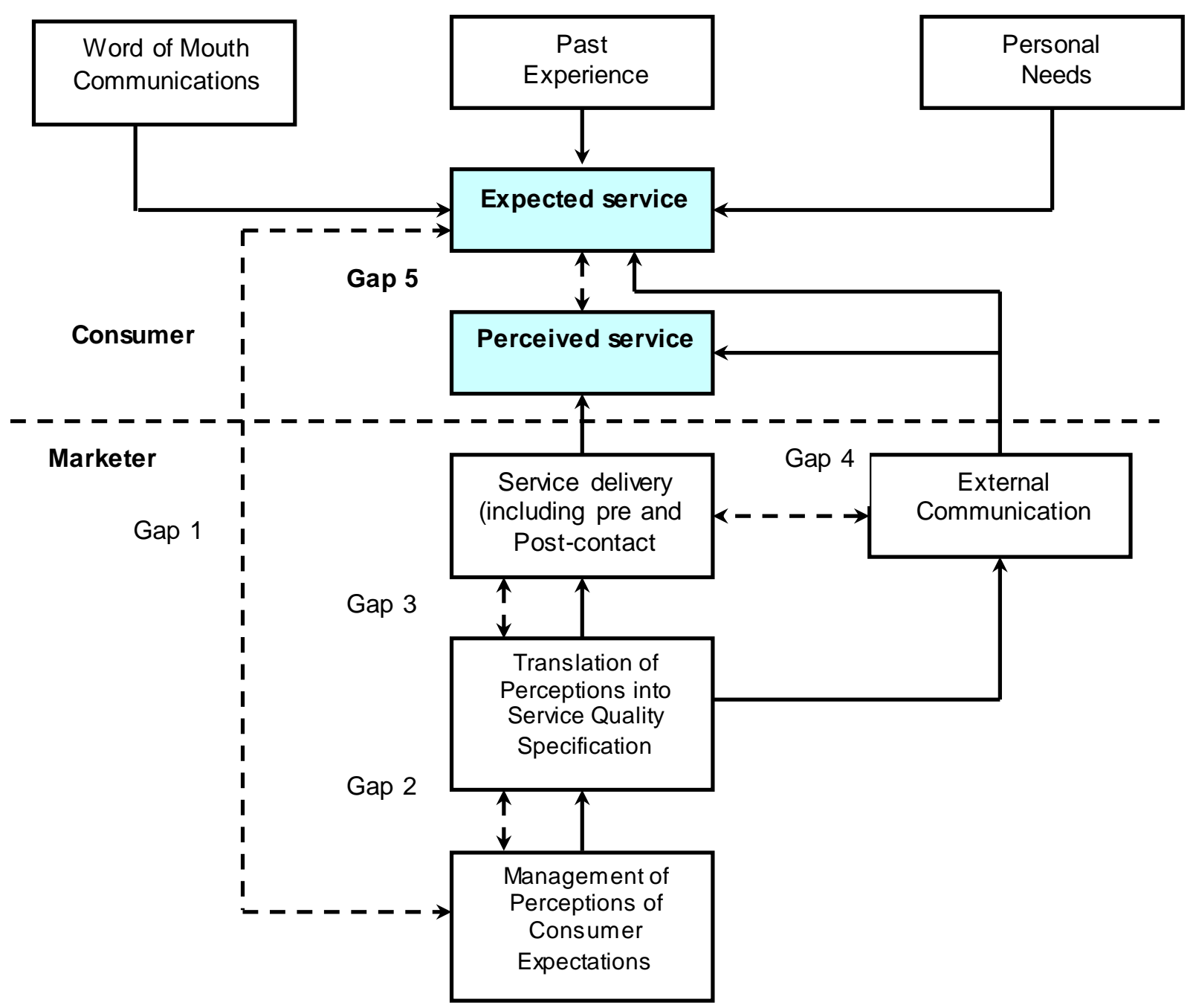

Figure: The gap model 


\section{Methodology}

Because SERVQUAL was initially designed for the assessment of service within the financial sector, the scale developed by Saleh and Rayan (1991), based upon SERVQUAL model, for measuring service quality in hospitality industry was refined and used in this study. Respondents were asked to indicate their expectations and perceptions of hospitality services at three Egyptian heritage sites, namely: Greater Cairo, Luxor and Minia. Hotels around these sites were selected for distributing the questionnaire. The respondents were handed questionaires at the entrance of hotels and/or at the heritage sites (foreigner and local customers). The questionnaire had four main sections. The first section concerns the demographic data of customers, i.e. their gender, age, educational background and nationality. The second section asked the respondents about their visit, i.e. purpose of visit, number of previous visits and number of nights. The third section evaluates the service quality by responding to thirty items/factors (or sub-attributes) in a format of five-point Likert scale, ranging from (1) "highly satisfied" to (5) "highly dissatisfied". The fourth section of the questionnaire pinpoints any additional important factors not included in the original list of factors or attributes and/or any comments or suggestions. Cronbach's alpha for each dimension was between 0.702 and 0.901 thus ensuring the reliability of the scale.

The size of the research sample was decided based upon the work of previous studies (i.e. Saleh and Rayan 1991 and Chow et al., 2007) despite the bigger size of the current research compared to those studies. Six hundred questionnaire forms were distributed; two hundred at each site. Four hundred and thirty four forms were valid for analysis.

With regard to data analysis, the Statistical Package for Social Science (SPSS) version 19 was used. Frequencies were used to analyze the profile of the respondents. Descriptive statistics and Paired sample ttest was used to compare between customer expectations and perceptions. Customer comments to open added questions were also analyzed and added to the results of the study.

\section{Results and Discussion}

The results are divided into two main parts. Part one presents the profile of respondents; part two compare s customer expectations with perceptions and identifies the most important factors (or attributes) that should be considered by the management to meet customer expectations.

\section{Respondents' Profile}

The profile of respondents ( Table 2) shows that $52 \%$ of the respondents were female and $48 \%$ were males. More than $50 \%$ of the respondents were of 34 years of age or less, The majority of the respondents $(71 \%)$ were holding university degrees and $21 \%$ of them were holding master or doctorate degrees. 
Table 2: Respondents' profile

\begin{tabular}{|c|c|c|c|}
\hline & & No. of respondents & Percentage $(\%)$ \\
\hline \multirow[t]{2}{*}{ Gender } & Male & 210 & 48 \\
\hline & Female & 224 & 52 \\
\hline \multirow[t]{4}{*}{ Age } & under 18 years & 8 & 2 \\
\hline & 18 to 34 years & 215 & 49 \\
\hline & 35 to 60 years & 116 & 27 \\
\hline & Over 60 years & 95 & 22 \\
\hline \multirow{4}{*}{$\begin{array}{l}\text { Educational } \\
\text { background }\end{array}$} & High school or less & 12 & 3 \\
\hline & University degree & 310 & 71 \\
\hline & Master or doctorate & 89 & 21 \\
\hline & Others & 23 & 5 \\
\hline \multirow[t]{2}{*}{ Nationality } & Egyptian & 82 & 19 \\
\hline & Foreigner & 352 & 81 \\
\hline \multirow[t]{4}{*}{ Purpose of Visit } & Recreational & 295 & 68 \\
\hline & Educational & 80 & 18 \\
\hline & Business & 39 & 9 \\
\hline & Others & 20 & 5 \\
\hline \multirow{4}{*}{$\begin{array}{l}\text { Number of } \\
\text { nights }\end{array}$} & One night & 70 & 16 \\
\hline & Up to three night & 181 & 42 \\
\hline & Up to seven nights & 173 & 40 \\
\hline & Over seven nights & 10 & 2 \\
\hline
\end{tabular}

In addition, most of the respondents were foreigners (81\%), mainly from Western Europe who are often interested in visiting Egyptian heritage sites, and only 19\% were Egyptian. Most of the respondents were on a recreational visit (68\%) followed by educational visit (18), business (9) and other purposes, e.g. family or friend visit (5\%). Respondents who spent up to three nights account for $40 \%$ as against 40 for up to seven nights and $16 \%$ for only one night and $2 \%$ for more than seven nights. 


\section{A comparison between customer expectations and perceptions}

Table 3 shows the mean rank of the thirty factors or sub-attributes in relation to both customer expectations and perceptions. It is interesting that the mean rank of all the thirty factors of customer expectations were lower than all the sub-attributes of customer perceptions. This means that the quality of services does not meet customer expectation. This also confirms that customers were not satisfied with the service quality.

With regard to the tangibility of hospitality services, the mean ranks for all expectations' factors were lower than those of perceptions confirming that customers were less satisfied with hospitality services. The expectations' factors mean ranks were between (1.10) for the factor "not offensive/sarcastic" and (1.79) for the factor "visually appealing facilities", whereas the mean ranks of perceptions' factors were (1.72) and (2.43) for the same factors respectively. The mean ranks (Table 3) showed that customers were more concerned with communications of both employees and their managers with customers more than the appearance of physical facilities, equipment, and personnel.

In addition, the mean ranks of all expectations' factors related to reliability were lower than the mean ranks of the same perceptions' factors. This means that the customer believes that the employee has no ability to perform the promised service dependably and accurately. Similarly, the mean ranks of all expectations' factors related to responsiveness, assurance and empathy were lower than the mean ranks of the same perceptions' factors. This indicates that the customers argued that hospitality organisations at the three heritage sites do not provide a prompt, courteous, secure and proper service. The Customers also agreed that no proper efforts have been taken to understand customers' needs and to meet such needs. Again, this affects customers' satisfaction and ultimately their loyalty. 
Table 3 Mean Scores of attributes

\begin{tabular}{|c|c|c|}
\hline & Customer expectations & Customer perceptions \\
\hline \multicolumn{3}{|l|}{ Tangibles } \\
\hline 1. Well dressed and neat & 1.27 & 1.67 \\
\hline 2. Have up-to-date equipment & 1.42 & 1.74 \\
\hline 3. Exhibit good manners & 1.16 & 1.69 \\
\hline 4. Smile at work & 1.35 & 1.93 \\
\hline 5. Visually appealing facilities & 1.79 & 2.43 \\
\hline 6. Not offensive/sarcastic & 1.10 & 1.72 \\
\hline \multicolumn{3}{|l|}{ Reliability } \\
\hline 7. Supportive employees & 1.33 & 2.12 \\
\hline 8. Performing service right the first time & 1.12 & 1.98 \\
\hline 9. Dependable in handling guests' problem & 1.28 & 1.96 \\
\hline 10. Providing service as promised & 1.15 & 2.33 \\
\hline \multicolumn{3}{|l|}{$\underline{\text { Responsiveness }}$} \\
\hline 11. Helpful even while busy & 1.42 & 2.30 \\
\hline 12. Inform about service & 1.22 & 2.01 \\
\hline 13. Check guest satisfaction & 1.09 & 2.17 \\
\hline 14. Greet guests as soon as possible & 1.70 & 2.11 \\
\hline 15. Prompt service to guest & 1.40 & 2.55 \\
\hline 16. Solve complaints & 1.35 & 1.99 \\
\hline 17. Cater services to guests & 1.38 & 2.11 \\
\hline 18. Inform about activities & 1.78 & 2.17 \\
\hline \multicolumn{3}{|l|}{ Assurance } \\
\hline 19. Trustworthy employees & 1.23 & 1.97 \\
\hline 20. Polite to guests & 1.15 & 1.87 \\
\hline 21. Communicate with guests & 1.47 & 2.20 \\
\hline 22. Kind and cordial tone & 1.46 & 2.05 \\
\hline 23. Advise undecided guests & 1.88 & 2.18 \\
\hline
\end{tabular}




\begin{tabular}{|l|c|c|}
\hline 24. Knowledgeable to answer guest questions & 1.76 & 2.23 \\
\hline 25. Don't narrate problems & 1.32 & 1.94 \\
\hline Empathy & 1.77 & 2.37 \\
\hline 26. Individual attention and treatment & 1.97 & 2.44 \\
\hline 27. Anticipate guests' needs & 1.21 & 2.06 \\
\hline 28. Respect guests & 1.28 & 1.95 \\
\hline 29. Serve individual needs & 2.01 & 2.40 \\
\hline 30. Address guests by name & & \\
\hline
\end{tabular}

Using the Paired sample t-test to compare between customers' expectations and their perceptions, the results showed a statistical significant difference between expectations and perceptions of hospitality services in the five main attributes: intangibility, reliability, responsiveness, assurance and empathy (P-Value, 0.000). In other words the results confirmed a gap between customer expectations and perceptions in all attributes. Precisely customers did not perceive the quality of hospitality service as they expected (Table 4).

Table 4 Gap between customer expectations and perceived service provision

\begin{tabular}{|l|c|c|c|c|}
\hline Attributes & $\begin{array}{c}\text { Customer expectations } \\
(1)\end{array}$ & $\begin{array}{c}\text { Customer perceptions } \\
(2)\end{array}$ & $\begin{array}{c}\text { Paired } \\
\text { sample } \\
\text { t-test }\end{array}$ & $\begin{array}{c}\text { Differences (1- } \\
2)\end{array}$ \\
\hline Tangibles & 1.39 & 1.86 & .000 & -0.47 \\
\hline Reliability & 1.22 & 2.10 & .000 & -0.88 \\
\hline Responsiveness & 1.42 & 2.18 & .000 & -0.76 \\
\hline Assurance & 1.48 & 2.04 & .000 & -0.56 \\
\hline Empathy & 1.65 & 2.24 & .000 & -0.59 \\
\hline
\end{tabular}

The customers commented about hospitality services at the heritage area. They agreed that the services provided are very poor and do not meet neither their expectations nor international standards. These services include toilets, setting areas, directions and notes, food and drink...etc. Many customers commented that the toilets are not often clean or sanitized, besides being too few to meet the number of customers/visitors. Also there were no setting areas or if available they were in a very poor condition. There were also poor signs for directions and notes that help customers in their visits to the heritage sites.

The customers also commented about the poor food and drink services inside and/or around the heritage sites. This is particularly true in Minia and Luxor, where the declared issue about food variety and safety, sanitation and personal hygiene of the workers adversely affects not only customer satisfaction but also the image of destination and it competitiveness. 


\section{Conclusion and Implication}

The findings showed that customers' perceptions of hospitality services at the three Egyptian heritage sites were lower than expectations. This means improper service quality provided to such customers. The gap between customer expectation and perceived service was significant at 0.000 for all the thirty factors or subattributes.. This might be due to the underestimation of customer expectations and thus providing poor quality services to them.

The results send an important message to hotel managers that unless major attention is paid to the planning of the hospitality services, dissatisfied customer will be the outcome. Hospitality organisations should design their services based on customers' need rather than on what the management of these organisations able to provide. Customer expectations should be identified and met by the hospitality organisations at the Egyptian heritage sites, besides considering the heterogeneity of the customers and their needs.

Further research is needed to compare between the different heritage sites in Egypt, and to investigate the differences in perceptions among various customers within the heritage site, e.g. German versus English customers. Another research opportunity is to focus on how the gap between customer expectations and perceptions could be bridged.

\section{References}

Chow, I. H; Lau, V. P; Lo, T. W; Sha, Z. and Yun, H. (2007) Service Quality in Restaurant Operations in China: Decision- and Experiential-oriented Perspectives. International Journal of Hospitality Management, 26 (3), 698-710.

Clark, M. A. and Wood, R. C. (1998) Consumer Loyalty in the Restaurant Industry - A Preliminary Expectation of the Issues. International Journal of Contemporary Hospitality Management, 10 (4), 139-144.

Douglas, L. and Connor, R. (2003) Attitude to Service Quality - the Expectation Gap. Nutrition and Food Science, 33 (4), 165-172.

Hacle, P. and Westlund, A. H. (2000) On Structural Equation Modelling for Customer Satisfaction Measurement. Total Quality Management, 11 (4-6), 820-825

Parasuraman, A; Zeithaml, V. A. and Berry, L. (1985) A Conceptual Model of Service Quality and Its Implications for Future Research. Journal of Marketing, 49 (4), 41-50.

Reblendo, M. A. (2001) Measuring and Managing Service Quality: Integrating Customer Expectations. Managing Service Quality, 11 (1), 22-31.

Saleh, F. and Rayan, C. (1991) Analysing Service Quality in the Hospitality Industry using SERVQUAL Model. The Service Industries Journal, 11 (3), 324-343.

Venetis, K. A. and Ghauri, P. N. (2004) Service Quality and Customer Retention: Building Long-term Relationship. European Journal of Marketing, 38 (11-12), 1577-1598.

Zeithmal, V. A; Parasuraman, A. and Berry, L. L. (1990) Delivery Quality Service. New York, The Free Press.

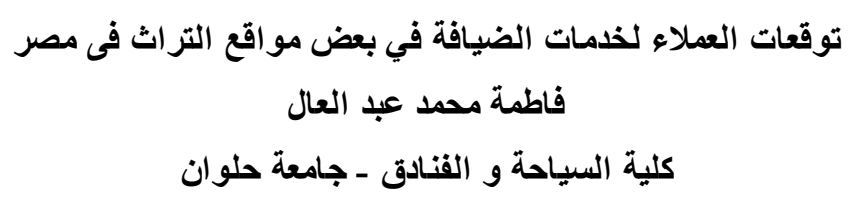

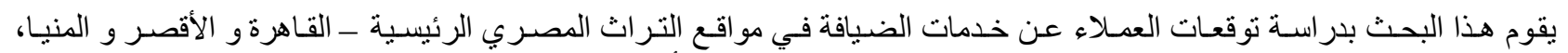

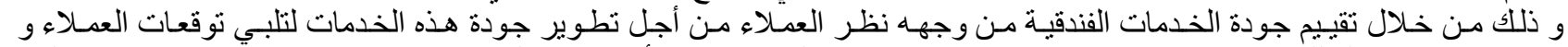

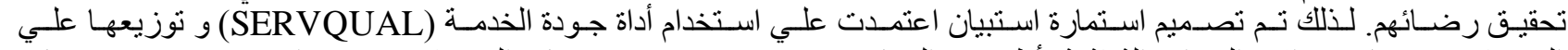

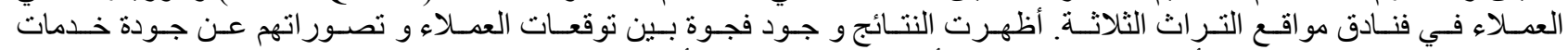

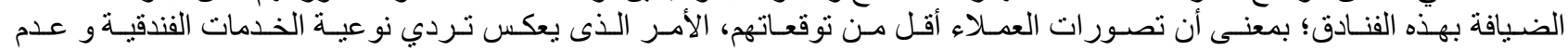

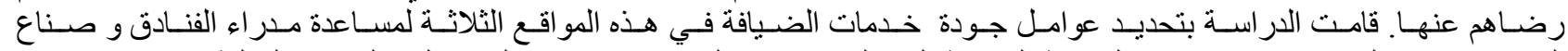

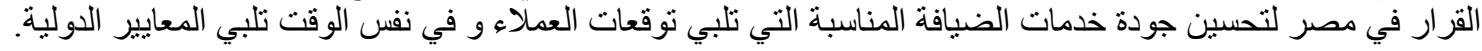

